\title{
Origin of colour after firing feldspar-quartz raw material from the Sobotka region (Lower Silesia, SW Poland)
}

\author{
Ewa Lewicka ${ }^{1, a}$ \\ ${ }^{1}$ MEERI, Polish Academy of Sciences, 30-261 Krakow, Wybickiego 7, Poland
}

\begin{abstract}
The article presents the studies of feldspar-quartz raw material from deposits in the Strzegom-Sobotka massif (Lower Silesia, SW Poland). The goal of this paper was to establish the causes of colour variation of samples after firing at $1200^{\circ} \mathrm{C}$. The scope of research encompassed among others a detailed chemical analysis of raw material and Mössbauer studies of two selected samples, as well as measurements of colour parameters after firing $\left(L^{*}, a^{*}, b^{*}\right)$. The chemical analysis revealed that the samples of darkest colours are characterized by the highest contents of: $\mathrm{Fe}_{2} \mathrm{O}_{3}, \mathrm{MnO}, \mathrm{Th}, \mathrm{U}, \mathrm{Ce}, \mathrm{Nd}$. The Mössbauer studies demonstrated the quantitative predominance of $\mathrm{Fe}^{2+}$ over $\mathrm{Fe}^{3+}$ in the sample of relative darker hue, while its spectra parameters suggest that $\mathrm{Fe}^{2+}$ is located in octahedral coordination that can result in cold blue tint. Ions $\mathrm{Fe}^{3+}$, occupying probably the tetrahedral sites, prevail in the other analysed sample, which probably causes its warm, reddish shade. The above-mentioned examinations lead to the finding that colour of analyzed samples after firing originates from ions of transition elements of various valence states and coordination (especially iron), as well as some REE and actinides.
\end{abstract}

\section{Introduction}

Colour is one of the primary diagnostic characteristics of minerals. It is also one of key parameters of ceramic raw materials, which determines aesthetic qualities of ceramic bodies obtained in course of their firing. The main components of ceramic mixes used in the domestic ceramic industry are feldspar-quartz raw materials from deposits of granitoids in the Sobotka region (Lower Silesia, SW Poland). The research, are presented in the paper focuses on explanation of the reasons for differentiation of colour of the samples from these deposits after firing at $1200{ }^{\circ} \mathrm{C}$.

Interpretation of colour origin is a complex issue which requires the use of four distinct physical theories, that is crystal field, molecular orbital, and the bands one, as well as physical optics. These theories explain the role of main constituents, admixtures/impurities, structural defects and specific structure of a mineral in creating the visual effect recognized as a certain colour [1-2].

The crystal field theory refers basically to colour of ionic crystals which prevail in the minerals world. In the crystal lattice of these minerals there are ions of transition elements or some REE (lanthanides) and actinides characterized by partially filled $d$ or $f$ shells. Unpaired electrons present on these shells can interact with visible light that results in absorption and colour. Transition metals such

\footnotetext{
${ }^{\mathrm{a}}$ Corresponding author: lewicka@min-pan.krakow.pl
} 
as $\mathrm{Fe}, \mathrm{Ti}, \mathrm{V}, \mathrm{Cr}, \mathrm{Mn}, \mathrm{Co}, \mathrm{Ni}, \mathrm{Cu}$, as well as some REE (Ce, Nd, Pr) and actinides (U, Th) may constitute the major ingredient of a mineral (e.g. either turquoise or malachite being copper compounds) or may be present in the lattice as an impurity (e.g. Fe in citrine, $\mathrm{Cr}$ in ruby or emerald). Sometimes a colour can be a result of a presence of colour centres, i.e. lattice defects that can absorb visible light, e.g. smoky quartz or blue Maxixe-type irradiated beryl [1].

In the molecular orbital theory the colours are associated with electron transfer between different ions neighbouring in the lattice of a mineral. This refers to the transfer between differently charged metal ions $\left(\mathrm{Fe}^{2+}-\mathrm{Fe}^{3+}, \mathrm{Fe}^{2+}-\mathrm{Ti}^{4+}\right)$, metal and non-metal or between two ions of non-metal. The examples are: blue sapphire, crocoite, vivianite. Apart from the valence state, the colour can be influenced by ion coordination. It was found that even small amount of $\mathrm{Fe}^{3+}$ tetrahedrally coordinated can result in intense red-brown colour, while its location solely in octahedral position - green shade $[1,3-4]$. Minerals containing $\mathrm{Fe}^{2+}$ in octahedral coordination also have shades in green and blue.

The band theory applies to a wide range of minerals, especially metals. This theory treats electrons as belonging to the crystal as a whole. They are contributed by each atom in the crystal lattice and create energy bands. These electrons are relatively free to move throughout the whole crystal, which results in the high electrical and thermal conductivities as well as metallic lustre. The colour is connected with electron transfer between energy bands due to absorption of visible light. The examples are native metals being perfect conductors, i.e.: copper, silver, iron, as well as semiconductors such as galena, galena, proustite, pyrite, sulphur. However, the presence of certain impurities can considerably affect both the conductivity as well as the light absorption of a mineral, e.g. a few boron atoms per million carbon atoms in the lattice of diamond can result in a blue colour, while one nitrogen atom for every 100,000 carbon atoms gives its deep-yellow colour.

The colour of some minerals can be explained by physical optics involving scattering, diffraction, interference and dispersion of visible light. These phenomena can be related to either the structural features of mineral formations (regular lamellar intergrowth in labradorite, globular structure of opals, overlapping platelets of aragonite in pearl) or the presence of impurities, i.e. inclusions of coloured minerals (fuchsite in aventurine, hematite in sunstone) or bubbles of fluids or gases (moonstone). One other distinction is the colour deriving from interference in the tarnish film on altered bornite that depends on the film thickness, its refractive index and the nature of incident light.

The detailed investigation of the colour origin often requires highly sensitive methods of examinations as the colour can be caused by more than one of the above-mentioned mechanisms, as well as can be a result of either gamma, X or neutron irradiation, or high temperature. Furthermore, the same element can produce various colours (e.g. $\mathrm{Cr}$ - red ruby or green emerald). On the other hand one specific colour may be attributed to different elements/impurities, e.g. blue colour to copper, cobalt or boron (in shattuckite, spinel, and diamond, respectively).

\section{Materials and methods}

The subject of the research was 19 samples of leucogranites from 4 deposits located in the StrzegomSobotka massif of Lower Silesia (SW Poland), i.e.: Pagorki Wschodnie (4 samples), Pagorki Zachodnie (4 samples), Strzeblow I (9 samples) and Stary Lom (2 samples). They represent leucocratic rocks, created in the contact zone of granite magma intrusion with surrounding rocks as a result of alteration (auto metamorphism) of various varieties of granite [5]. This caused an enrichment of their mineral composition in feldspars (plagioclases and microcline-type perthite) and quartz with simultaneous depletion of micas that made them valuable raw material for the ceramic industry [6].

The mineral composition of all samples was determined by transmission-light microscopy in standard thin sections by the use of petrographic microscope Carl Zeiss Jena (Germany). Microstructural and phase observations were performed on fracture surfaces using a scanning electron microscope (HITACHI S-4700, Japan) in both secondary (SE) and back-scattered (BE) electron models after sputtering with a thin layer of carbon in order to ensure electrical conductivity. 
Qualitative EDS (NORAN Vantage system) analyses were carried out simultaneously with SEM observations in order to distinguish the various phases containing iron, REE and transition metals. The measurements were taken with the use of accelerating voltage $15-20 \mathrm{kV}$. Chemical analyses for oxides and trace elements contents were conducted in the Activation Laboratories Ltd. - ACTLABS of Ancaster in Canada by the following methods: inductively coupled plasma (FUS-ICP), by total digestion - inductively coupled plasma (TD-ICP) and instrumental neutron activation analysis (INAA). Two selected samples were examined by the Mössbauer spectroscopy method. The spectra were collected using the RENON MsAa-3 spectrometer at room temperature. The ${ }^{57} \mathrm{Co}(\mathrm{RH})$ isotope was used as a source of radiation. All spectra shifts were reported versus the total shift in $\alpha$-Fe. From the material of each sample, after grinding $\left(d_{90}=53.3 \mu \mathrm{m}\right)$, mixing with water and pressing, the standard pastilles were formed $(\phi 37 \mathrm{~mm} \times \mathrm{H} 7 \mathrm{~mm})$, which were fired at $1200^{\circ} \mathrm{C}$ in laboratory chamber furnace for $2 \mathrm{~h} 15 \mathrm{~min}$. The colour parameters of fired bodies were measured using UV-Vis spectrophotometer (Minolta 2300D, Japan) and the chromatic coordinates expressed as L*, a*, b*.

The aim of the study was to determine forms and concentrations of colouring elements (chromophores), especially of transition elements (mainly Fe and Ti), some REE and actinides, contents and relative proportions of $\mathrm{Fe}^{2+}$ and $\mathrm{Fe}^{3+}$ as well as establishing the relation of results of chemical composition and spectroscopic measurements to colour of samples after firing.

\section{Results and discussion}

The sample material consists of well characterized mineral components [7]. Both observations in transmission-light microscope and examinations using scanning electron microscope techniques (SEM-EDS) performed in back-scattered electrons bean (BSE) revealed the presence of minerals containing colouring components, i.e. transition elements: $\mathrm{Fe}, \mathrm{Ti}, \mathrm{Mn}, \mathrm{Ni}, \mathrm{V}$ and $\mathrm{Cu}$, as well as some REE (Ce, Nd) and actinides (Th, U). It was also shown by chemical analysis (Table 1). Other colouring elements such as $\mathrm{Cr}$ and $\mathrm{Co}$ were not detected, while the contents of $\mathrm{Ni}, \mathrm{Cu}$ and $\mathrm{V}$ were very low, and therefore are not mentioned in the Table 1. From the above-mentioned transition elements the dominant colour contributor was iron, the most plentiful in nature (about $5 \%$ of the earth crust). Its main mineral phases ascertain in the examined samples were as following: chlorites (containing up to $50 \% \mathrm{Fe}_{2} \mathrm{O}_{3}$ ), chloritized biotite (up to $40 \% \mathrm{Fe}_{2} \mathrm{O}_{3}$ ), light micas - muscovite, sericite (up to $53.7 \% \mathrm{Fe}_{2} \mathrm{O}_{3}$ ), rutile (up to $20.5 \% \mathrm{Fe}_{2} \mathrm{O}_{3}$ ), and $\mathrm{Fe}-\mathrm{Mn}$ garnets (up to $31 \% \mathrm{Fe}_{2} \mathrm{O}_{3}$ and $14.4 \%$ $\mathrm{MnO}$ ). It was less present in kaolinite $\left(1.0-4.7 \% \mathrm{Fe}_{2} \mathrm{O}_{3}\right.$ ), feldspars (occasionally up to 0.3-0.7\% $\mathrm{Fe}_{2} \mathrm{O}_{3}$ ), monazite (up to $1.23 \% \mathrm{Fe}$ ), sphalerite (up to $1.83 \% \mathrm{Fe}$ ), xenotime (up to $1.37 \% \mathrm{Fe}_{2} \mathrm{O}_{3}$ ), zircon (up to $0.7 \% \mathrm{Fe}_{2} \mathrm{O}_{3}$ ) and epidote, occurring in a form of very thin veins in feldspar grains (greenish colour in transmission-light microscope suggested that it can be pistacite - Fe-rich variety of epidote). There were also observed some iron own mineral phases, however in negligible amounts, i.e. pyrite and titanium magnetite or magnetite. Other minerals containing colouring elements detected in the samples were as following: chlorites, micas, garnets $(\mathrm{Mn})$, monazite (Th, $\mathrm{U}, \mathrm{Ce}$, and $\mathrm{Nd})$, rutile (Ti, V), zircon (U), and xenotime (Th, REE). Some REE can be also incorporated in feldspars as it was confirmed by Götze et al. [8] in investigations performed by high-resolution spectral CL. Scanning images of selected minerals rich in the above-mentioned elements in the examined samples are presented in Figure 1.

The results of chemical analysis of the examined samples revealed profound differentiation of the contents of colouring oxides, which was reflected by colours of fired samples and significant variation in the values of chromatic coordinates $\mathrm{L}^{*}, \mathrm{a}^{*}, \mathrm{~b}^{*}$ (Table 1, Fig. 2).

The values of $\mathrm{L}^{*}$ and $\mathrm{a}^{*}$ coordinates correlated with the contents of $\mathrm{Fe}_{2} \mathrm{O}_{3}$ in the majority of samples, i.e. higher $\mathrm{Fe}_{2} \mathrm{O}_{3}$ content, lower brightness $\left(\mathrm{L}^{*}\right)$ of the fired body and higher a* value (red tint) with relatively good match factor $\left(R^{2}\right)$ of the trend line to the experimental values (Figs. 3-4). High value of $b^{*}$ (yellow shade) can be correlated with $\mathrm{TiO}_{2}$ and also $\mathrm{Fe}_{2} \mathrm{O}_{3}$ contents, although the values of $R^{2}$ coefficient are low (Figs. 5-6). When comparing samples characterized by similar content 
of $\mathrm{TiO}_{2}$, which differs in $\mathrm{Fe}_{2} \mathrm{O}_{3}$ contents, it can be noted that $\mathrm{b}^{*}$ value is lower in the samples enriched in iron.
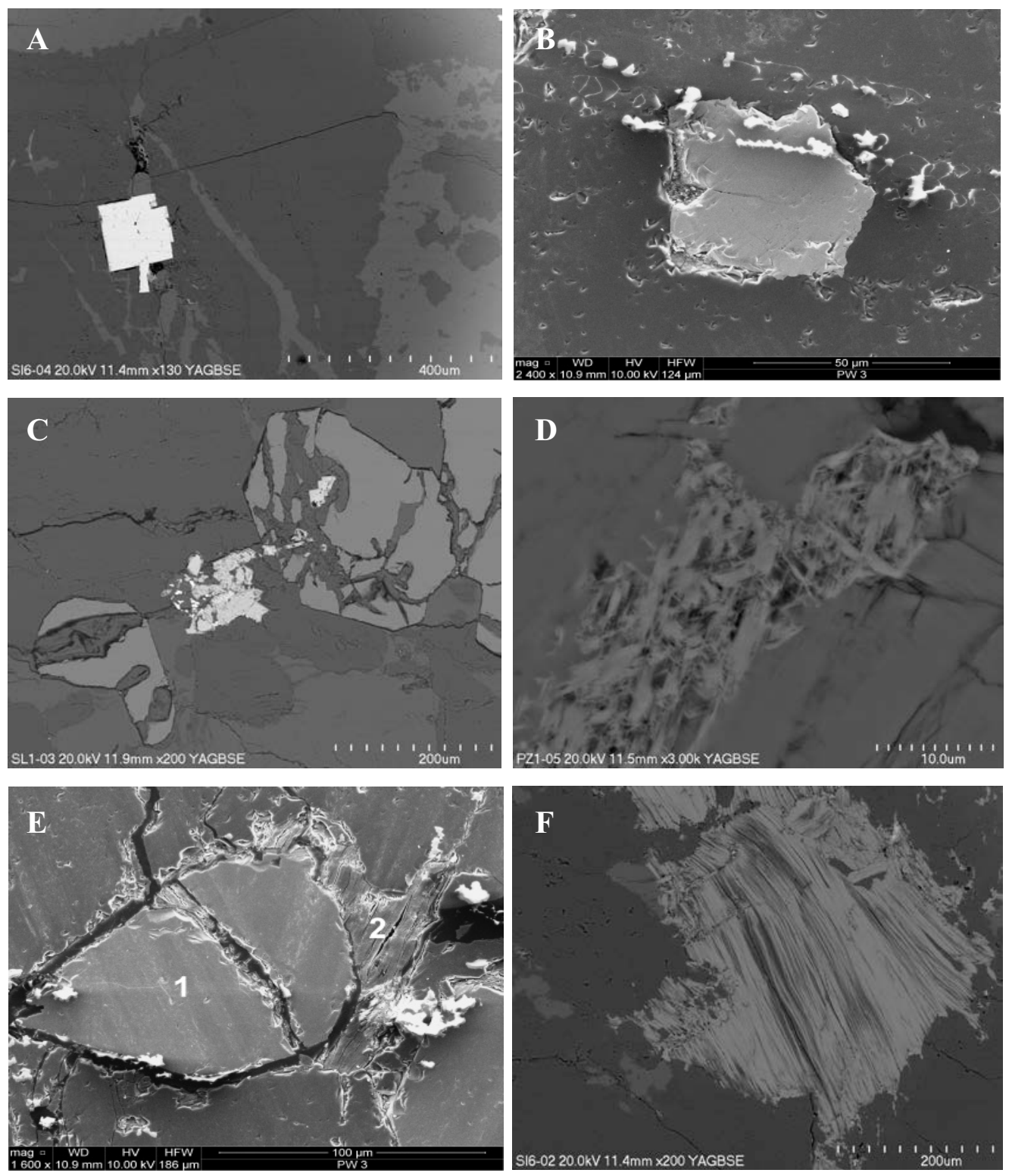

Figure 1. Selected minerals containing colouring elements in granitoids from deposits in the Sobotka region (SEM-EDS): A - pyrite (Strzeblow I), B - monazite (Pagorki Wschodnie), C - Fe-Mn garnets with inclusions of zircon and Th-rich monazite in the centre (Stary Lom), D - rutile (Pagorki Zachodnie), E - Fe-Mn garnet (1), next to chloritized biotite (2) (Pagorki Wschodnie), F - Fe-rich biotite (Strzeblow I) 
Table 1. Contents of selected colouring components and values of colour parameters after firing the samples from: Pagorki Zachodnie (PZ), Pagorki Wschodnie (PW), Stary Lom (SL), Strzeblow I (SI) deposits

\begin{tabular}{|c|c|c|c|c|c|c|c|c|c|c|}
\hline Sample & $\begin{array}{c}\mathbf{F e}_{\mathbf{2}} \mathbf{O}_{\mathbf{3}} \\
{[\mathbf{\%}]}\end{array}$ & $\begin{array}{c}\mathbf{T i O}_{\mathbf{2}} \\
{[\mathbf{\%}]}\end{array}$ & $\begin{array}{c}\mathbf{M n O} \\
{[\mathbf{\%}]}\end{array}$ & $\begin{array}{c}\mathbf{T h} \\
{[\mathbf{p p m}]}\end{array}$ & $\begin{array}{c}\mathbf{U} \\
{[\mathbf{p p m}]}\end{array}$ & $\begin{array}{c}\mathbf{C e} \\
{[\mathbf{p p m}]}\end{array}$ & $\begin{array}{c}\mathbf{N d} \\
{[\mathbf{p p m}]}\end{array}$ & $\begin{array}{c}\mathbf{L}^{*} \\
{[\mathbf{\%}]}\end{array}$ & $\mathbf{a}^{*}$ & $\mathbf{b}^{*}$ \\
\hline PZ-1 & 0.43 & 0.052 & $<0.01$ & 12.2 & 5.6 & 25 & 12 & 58.68 & 8.86 & 7.32 \\
\hline PZ-2 & 0.33 & 0.073 & $<0.01$ & 12.8 & 1.8 & 40 & 24 & 69.98 & 5.86 & 9.27 \\
\hline PZ-3 & 0.19 & 0.095 & $<0.01$ & 12.9 & 2.5 & 22 & 9 & 82.64 & 0.68 & 9.60 \\
\hline PZ-4 & 0.34 & 0.048 & $<0.01$ & 20.2 & 5.1 & 33 & 10 & 61.37 & 6.05 & 5.59 \\
\hline PW-1 & 0.30 & 0.027 & 0.02 & 15.3 & 2.4 & 27 & $<5$ & 75.39 & 1.53 & 6.76 \\
\hline PW-2 & 0.65 & 0.021 & 0.11 & 9.4 & 16.2 & 19 & 10 & 57.67 & 3.52 & 3.20 \\
\hline PW-3 & 0.34 & 0.019 & 0.03 & 9.5 & 0.9 & 21 & 10 & 73.91 & 2.88 & 5.66 \\
\hline PW-4 & 0.22 & 0.020 & $<0.01$ & 13.6 & 1.7 & 21 & 9 & 83.26 & 1.50 & 6.35 \\
\hline SL-1 & 0.26 & 0.022 & 0.02 & 11.0 & 2.9 & 28 & 7 & 74.31 & 2.03 & 7.04 \\
\hline SL-2 & 0.28 & 0.019 & 0.03 & 17.5 & 2.6 & 40 & 24 & 66.96 & 1.22 & 1.83 \\
\hline SI-1 & 0.17 & 0.053 & $<0.01$ & 14.9 & 1.1 & 32 & 13 & 78.44 & 0.11 & 6.24 \\
\hline SI-2 & 0.25 & 0.060 & $<0.01$ & 12.6 & $<0.5$ & 24 & 10 & 75.93 & 2.90 & 7.70 \\
\hline SI-3 & 0.22 & 0.048 & $<0.01$ & 18.7 & 2.7 & 30 & 11 & 74.49 & 1.91 & 7.26 \\
\hline SI-4 & 0.31 & 0.050 & $<0.01$ & 22.3 & 2.3 & 29 & 14 & 70.99 & 2.92 & 6.03 \\
\hline SI-5 & 0.66 & 0.054 & $<0.01$ & 19.1 & 3.5 & 23 & 10 & 53.08 & 3.89 & 2.49 \\
\hline SI-6 & 0.60 & 0.056 & 0.01 & 14.7 & 7.5 & 18 & 5 & 52.79 & 4.92 & 4.07 \\
\hline SI-7 & 0.23 & 0.049 & $<0.01$ & 14.3 & 2.6 & 25 & 8 & 78.50 & 2.06 & 8.85 \\
\hline SI-8 & 0.31 & 0.065 & $<0.01$ & 21.5 & 4.9 & 29 & 18 & 75.23 & 3.88 & 9.10 \\
\hline SI-9 & 0.15 & 0.032 & $<0.01$ & 9.9 & 2.4 & 24 & $<5$ & 81.73 & 0.62 & 6.37 \\
\hline
\end{tabular}

Mössbauer spectroscopy studies were performed for two samples that distinctly differ in respect to $\mathrm{Fe}_{2} \mathrm{O}_{3}$ contents and colour after firing, i.e. PW-2 and PZ-2 (Tab. 1, Fig. 2). In the sample PW-2, one of the richest in $\mathrm{Fe}_{2} \mathrm{O}_{3}, \mathrm{MnO}$ and $\mathrm{U}$ among all examined samples $(0.65 \%, 0.11 \%$ and $16.2 \mathrm{ppm}$, respectively), a significant prevalence of the relative content of $\mathrm{Fe}^{2+}(69 \%)$ over $\mathrm{Fe}^{3+}(31 \%)$ was revealed (Table 2). That was probably, along with relatively large amount of these elements - the reason for cold, dark grey/blue shade of that sample (Table 1, Fig. 2). In the sample PZ-2 (containing $\left.0.33 \% \mathrm{Fe}_{2} \mathrm{O}_{3}\right) \mathrm{Fe}^{3+}$ cation dominated over $\mathrm{Fe}^{2+}$ (78\% and $22 \%$, respectively). It was characterized by a relatively high percentage of $\mathrm{TiO}_{2}, \mathrm{Ce}$ and $\mathrm{Nd}(0.073 \%, 40$ and $24 \mathrm{ppm}$, respectively). The value of isomer shift of $\mathrm{Fe}^{2+}(1.11 \mathrm{~mm} / \mathrm{s})$ in this sample indicated that ferrous ion probably occurred in the octahedral coordination as it was set for this cation in crystalline substances [9]. Simultaneously, the isomer shift of ferric ion in both samples $(0.30-0.35 \mathrm{~mm} / \mathrm{s})$ can refer to tetrahedral coordination in the crystal lattice which was found by Steffen et al. [10] as well as Spiering and Seifert [11] in their Mössbauer studies of silicate glasses of granitic composition. Therefore, it can be assumed that this ion determines the colour of both samples, however its influence coluld be modified by other elements, especially by titanium. In course of research on the redox equilibria of silica melts rich in $\mathrm{Fe}$ and $\mathrm{Ti}[12]$ it was proven that $\mathrm{Ti}^{4+}$ tended to enhance the stability of $\mathrm{Fe}^{3+}$ relative to that of $\mathrm{Fe}^{2+}$ due to the structural instability of the $\mathrm{Fe}^{2+}-\mathrm{O}-\mathrm{Ti}^{4+}$ network. In such a configuration, the following transfer of electron via oxygen atom was possible: $\mathrm{Fe}^{2+}-\mathrm{O}-\mathrm{Ti}^{4+} \rightarrow \mathrm{Fe}^{3+}-\mathrm{O}-\mathrm{Ti}^{+3}[13-14]$. It seems to be consistent with the fact that in the sample PZ-2, in which $\mathrm{Fe}^{3+}$ cations dominate, the content of $\mathrm{TiO}_{2}(0.07 \%)$ was much higher than in the PW-2 sample $(0.02 \%)$ marked by a predominance $\mathrm{Fe}^{2+}$ cations (Table 2 ). 
PZ-1

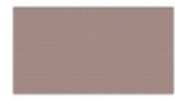

PW-1

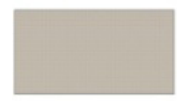

SL-1

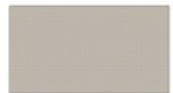

SI-1

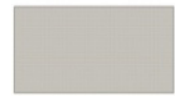

SI-5

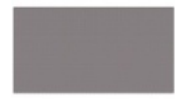

SI-6

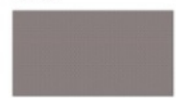

PZ-3

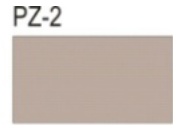

PW-2

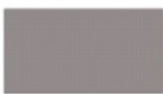

SL-2

SI-2

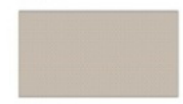

SI-9

PW-3

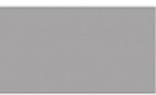

SI-3

SI-7

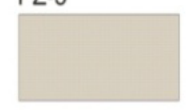

PZ-4

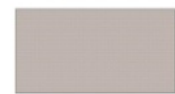

PW-4
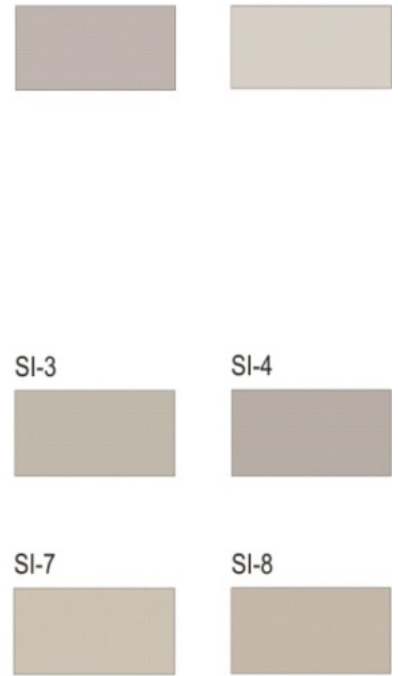

SI-8

SI-4
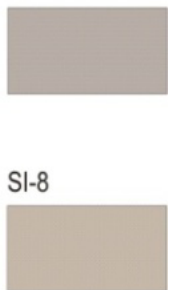

Figure 2. Colour of samples after firing in $1200{ }^{\circ} \mathrm{C}$.

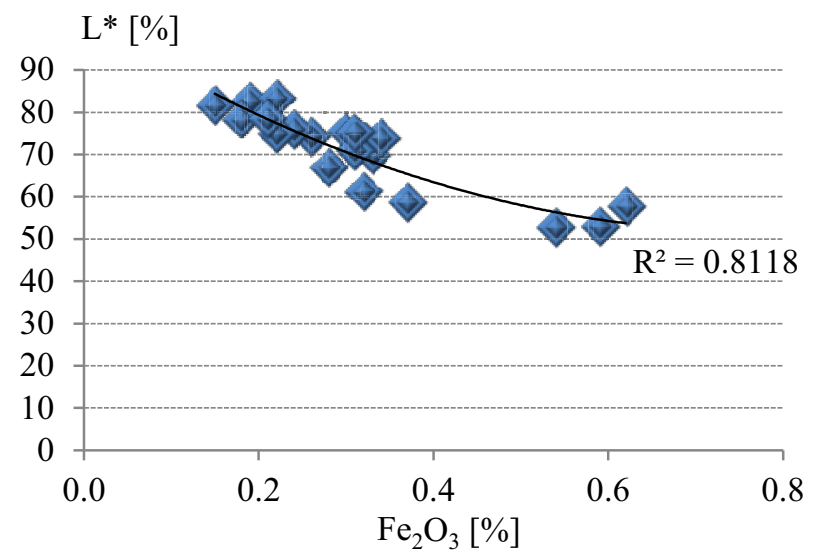

Figure 3. Content of $\mathrm{Fe}_{2} \mathrm{O}_{3}$ versus brightness of the samples after firing. 


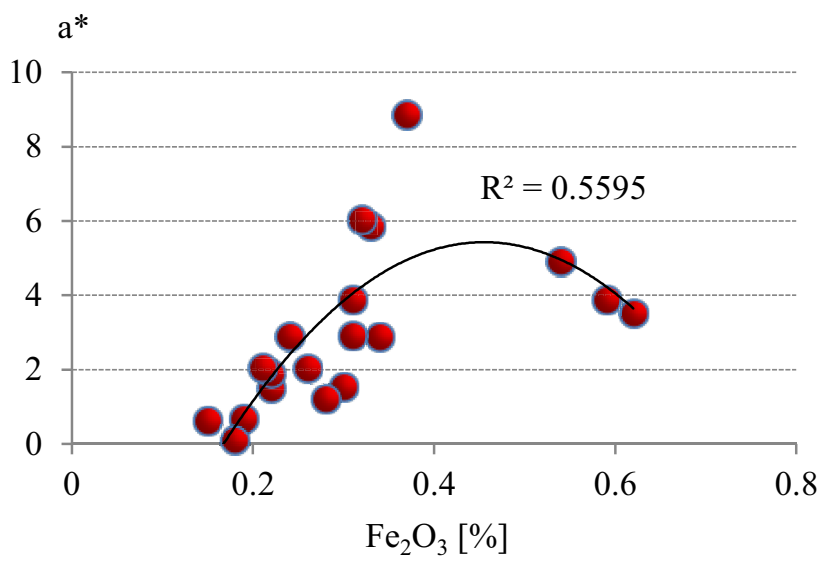

Figure 4. Content of $\mathrm{Fe}_{2} \mathrm{O}_{3}$ versus a* parameter of the samples after firing.

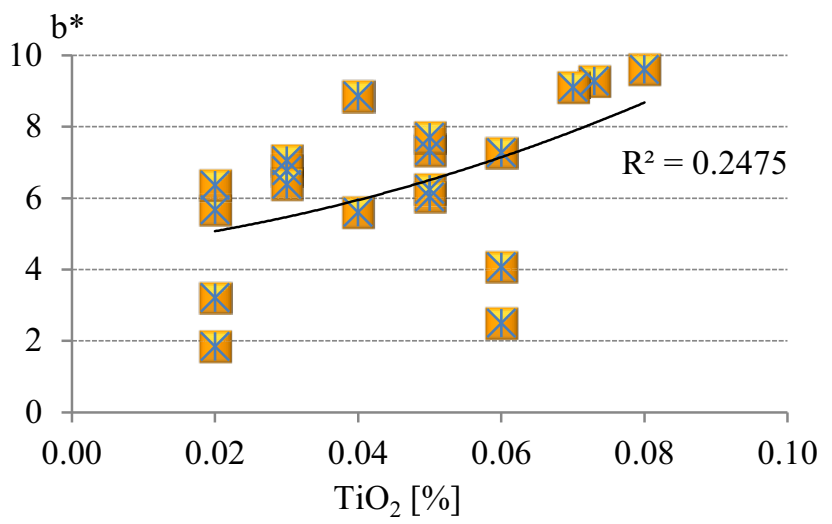

Figure 5. Content of $\mathrm{TiO}_{2}$ versus $\mathrm{b}^{*}$ parameter of the samples after firing.

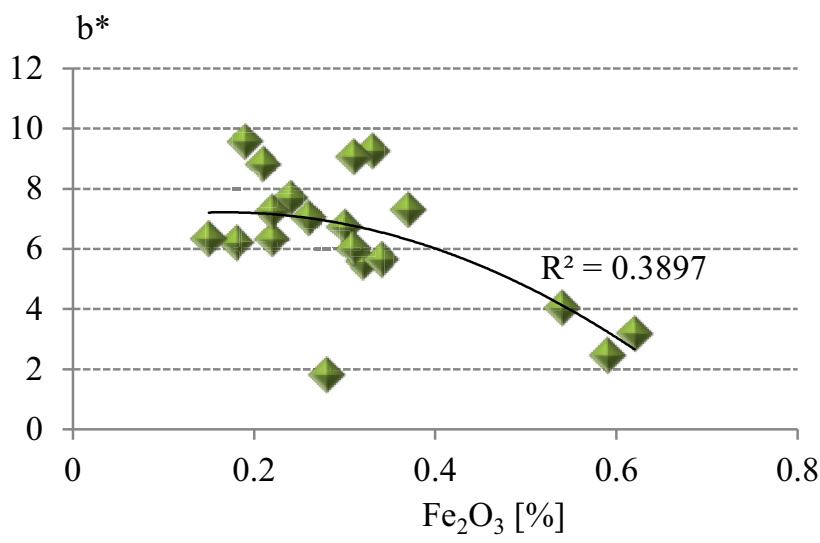

Figure 6. Content of $\mathrm{TiO}_{2}$ versus b* parameter of the samples after firing. 
Table 2. Parameters of the Mössbauer spectra of PW-2 and PZ-2 samples, where IS - isomer shift versus $\alpha$-Fe, QS - quadrupole splitting, $\mathrm{W}$ - relative content of iron of respective valence state.

\begin{tabular}{|c|c|c|c|c|}
\hline Sample & Cation & IS [mm/s] & QS [mm/s] & W [\% at.] \\
\hline \multirow{3}{*}{$\mathrm{PW}-2$} & \multirow{2}{*}{$\mathrm{Fe}^{2+}$} & $1.44 \pm 0.01$ & $3.22 \pm 0.01$ & 34 \\
\cline { 3 - 5 } & \multirow{3}{*}{$\mathrm{Fe}^{3+}$} & $0.99 \pm 0.01$ & $2.90 \pm 0.03$ & 35 \\
\cline { 2 - 5 } & $\mathrm{Fe}^{2+}$ & $0.30 \pm 0.05$ & $1.4 \pm 0.2$ & 14 \\
\cline { 2 - 5 } & $\mathrm{Fe}^{3+}$ & $0.35 \pm 0.02$ & $0.5 \pm 0.1$ & 17 \\
\hline \multirow{2}{*}{$\mathrm{PZ}-2$} & & $0.32 \pm 0.04$ & $2.9 \pm 0.1$ & 22 \\
\cline { 2 - 5 } & & \multicolumn{2}{|c}{$0.64 \pm 0.03$} & 78 \\
\hline
\end{tabular}

\section{Conclusions}

The investigation of granitoids from deposits in the Sobotka region by means of transmission-light microscopy, scanning microscopy, chemical analysis and Mössbauer spectroscopy showed that colour differentiation of the samples after firing can be related to the presence of transition metals, especially Fe and $\mathrm{Ti}$, some REE (Ce, Nd) and actinides (U, Th) in the structure of their mineral components. It seems to be consistent with the crystal field and molecular orbital theories.

The Mössbauer studies indicated that the colour can result from a combined effect of the presence of iron on various valence states and titanium, as in the case of sample with $\mathrm{Fe}^{3+}$ prevalence (PZ-2) which is characterized by high content of $\mathrm{TiO}_{2}$. Apart from the oxidation state, the colour is influenced by the site occupancy of iron, i.e. its either tetrahedral or octahedral coordination in the crystal lattice. The presence of $\mathrm{Fe}^{3+}$ tetrahedrally coordinated influences the colour much stronger than its location in the octahedral position, resulting in the red-brown colour, on the other hand exclusive octahedral occupancy of $\mathrm{Fe}^{3+}$ can produce the green colour (vide [3]). Ion of $\mathrm{Fe}^{2+}$ octahedrally coordinated gives shades in green and blue. The isomer shift of the PZ-2 spectrum suggests tetrahedral coordination of $\mathrm{Fe}^{3+}$ that can be attributed to brown-reddish colour of this sample, while another one PW-2 - showed a predominance of $\mathrm{Fe}^{2+}$ in probably octahedral coordination that could result in its cold dark colour with grey/blueish hue.

\section{References}

1. K. Nassau, Am. Miner. 63, 219 (1978)

2. A. Bolewski, J. Kubisz, W. Żabiński, Mineralogia ogolna (Wyd. Geol., Warszawa, 1981)

3. W. Sikora, Prace Miner, 39 (Wyd. Geol., Warszawa, 1974)

4. A. Bolewski, M. Budkiewicz, P. Wyszomirski, Surowce ceramiczne (Wyd. Geol., Warszawa, 1991)

5. M. Niec, Surowce mineralne Polski. Surowce skalne. Surowce krzemionkowe i skaleniowe, edited by R. Ney, 101 (Wyd. IGSMiE PAN, Krakow, 2005)

6. E. Lewicka, Surowce mineralne Polski. Surowce skalne. Surowce krzemionkowe i skaleniowe [ed. R. Ney], 139-155 (Wyd. IGSMiE PAN, Krakow, 2005)

7. E. Lewicka, Min. Res. Manag., 31(1), 81 (2013)

8. J. Götze, D. Haberman, R. D. Neuser, D. K. Richter, Chem. Geol., 153, 81 (1999)

9. G. M. Bancroft, Mössbauer Spectroscopy (McGraw Hill, London, 1973)

10. G. Steffen, F. A. Seifert, G. Amthauer, Am. Miner., 69, 339 (1984)

11. B. Spiering, F. A. Seifert, Contrib. Mineral. Petrol., 90, 63 (1985).

12. H.V. Alberto, J.M. Gil, N. Ayres DeCampos, B.O. Mysen, J. Non-Cryst. Solids, 151(1-2), 39 (1992)

13. C. E. Weaver, Clays Clay Miner., 24, 215 (1976)

14. S. Chyandrasekhar, S. Ramaswamy, Appl. Clay Sci., 21, 133 (2002) 